Journal of EST, Volume 1, Nomor 1 Juni 2015 hal 27- 38

ISSN: 2460-1497

\title{
PENGEMBANGAN MATERI PEMBELAJARAN MAKASSAR BAGI SISWA SMP/MTs. DI SULAWESI SELATAN
}

\author{
Kembong Daeng \\ Ahli Bahasa dan sastra \\ FBS Universitas Negeri Makassar \\ Email: kembongdaeng@unm.ac.id
}

\begin{abstract}
This research aims at yielding product of Makassar Language learning material for Junior High School or Islamic Junior High School students which is feasible in terms of context, language, and presentation. The research design employed refers to Four-D Research Development conducted by Thiagarajan (1974:5) through four stages, which are (1) defining; (2) planning; (3) developing, and (4) disseminating. The research data is analyzed by using domain analysis technique with critical and reflective principles. This learning material is validated by the experts of language teaching, linguists and literature experts and has been tested to Makassar Language Teachers SMP/MTs in Makassar city as the field practitioners. The research finding describes that after this product is revised, the final assessment result of this product shows that this product is highly feasible. Likewise, the test result of the practitioners (teachers) in the field is also in highly feasible category. This research result shows that the developed product of Makassar language learning material can be used as one of Makassar language teaching resources in South Sulawesi
\end{abstract}

Keywords: the development of learning materials, Makassar languages, student.

\begin{abstract}
ABSTRAK
Penelitian ini bertujuan untuk menghasilkan produk materi pembelajaran bahasa Makassar bagi siswa SMP/MTs. yang layak dari segi isi, bahasa, dan penyajian. Desain penelitian yang digunakan mengacu pada penelitian pengembangan Four-D oleh Thiagarajan (1974:5) yang melalui empat tahap, yaitu (1) pendefinisian; (2) perencanaan ; (3) pengembangan, dan (4) penyebarluasan. Data penelitian dianalisis dengan teknik analisis domain dengan prinsip kritis dan reflektif. Materi pembelajaran ini divalidasi oleh pakar pengajaran bahasa, linguistik, dan pakar sastra serta diujicobakan kepada guru bahasa Makassar tingkat SMP/MTs di Kota Makassar sebagai praktisi di lapangan...Temuan penelitian menggambarkan bahwa setelah produk ini direvisi, maka hasil penilaian produk akhir berada pada kategori sangat layak. Demikian pula hasil uji coba praktisi (guru) di lapangan berada pada kategori sangat layak. Hasil penelitian ini menunjukkan bahwa produk materi pembelajaran bahasa Makassar yang telah dikembangkan dapat digunakan sebagai salah satu sumber bahan ajar bahasa Makassar di Sulawesi Selatan.
\end{abstract}

Kata Kunci: pengembangan materi pembelajaran, bahasa Makassar, siswa SMP/MTs. 


\section{PENDAHULUAN}

Bahasa Makassar merupakan salah satu kearifan lokal masyarakat Sulawesi Selatan yang masih digunakan sebagai alat komunikasi oleh masyarakat pendukungnya. Namun, dalam era globalisasi, bahasa ini semakin terpinggirkan dan kurang diminati. Masyarakat tutur lebih memilih menggunakan bahasa nasional dan bahasa asing dalam berkomunikasi dibanding bahasa Makassar. Johar (2010) dalam penelitiannya mengungkapkan bahwa kebanyakan masyarakat Pangkajene Kepulauan (Pangkep) memilih menggunakan bahasa Indonesia dalam lingkungan rumah tangga dengan pertimbangan kemaslahatan. Penggunaan bahasa Indonesia sebagai pilihan yang menjanjikan karena dianggap memiliki nilai kemaslahatan yang lebih banyak dibanding menggunakan bahasa daerah. Demikian juga halnya di sekolah. Siswa kurang tertarik belajar bahasa daerah karena pembelajaran bahasa daerah tidak dikelola dengan baik seperti mata pelajaran yang lain.

Pembelajaran Bahasa Makassar (BM) yang baik dapat diwujudkan apabila didukung oleh beberapa faktor, di antaranya: terpenuhinya guru BM yang profesional, tersedianya kurikulum dan materi pembelajaran BM yang sesuai dengan kebutuhan, dan sarana pembelajaran lainnya yang dapat meningkatkan kualitas pembelajaran. Kurangnya minat siswa belajar bahasa daerah di Sulawesi Selatan, termasuk bahasa dan sastra Makassar antara lain disebabkan oleh kurangnya bahan ajar yang layak digunakan oleh siswa. Hasil survey pada beberapa buku ajar BM yang digunakan di sekolah, ditemukan beberapa kelemahan, antara lain: isinya belum memuat aspek pengetahuan bahasa dan sastra Makassar, belum menanamkan sikap dan karakter bangsa, dan belum melatih keterampilan berbahasa dan bersastra Makassar; bahasa yang digunakan kurang komunikatif dan penulisannya masih banyak yang menyalahi kaidah penulisan BM, dan teknik penyajian serta desain gambar yang kurang menarik (Daeng, 2013).

Masalah utama yang dihadapi guru dalam mengajarkan bahasa Makassar adalah belum adanya bahan ajar yang sesuai dengan kurikulum. Akibatnya, guru bahasa Makassar belum dapat mengajarkan BM secara baik dan benar. Salah satu upaya pembinaan dan pengembangan $\mathrm{BM}$ adalah melalui inovasi pengembangan materi pembelajaran yang dapat digunakan untuk meningkatkan minat belajar siswa belajar bahasa makassar. Materi pembelajaran yang disusun ini, berdasarkan silabus dan berisikan sikap, pengetahuan, dan keterampilan yang harus dikuasai siswa untuk mencapai standar kompetensi, kompetensi dasar, dan indikator yang telah ditetapkan (Depdiknas, 2011). Selanjutnya, Tomlinson (2007:193) mengemukakan bahwa materi pembelajaran bahasa merujuk kepada segala sesuatu yang digunakan oleh pengajar atau siswa untuk memudahkan belajar bahasa, meningkatkan pengetahuan, dan pengalaman belajar berbahasa.

Pembelajaran BM sebagai pelajaran muatan lokal memegang peranan penting dalam kehidupan sosial-budaya masyarakat Makassar, yakni sebagai sarana pembinaan dan pengembangan budaya Makassar. Fungsi pembelajaran BM diselaraskan dengan kedudukan BM sebagai bahasa daerah dan sastra Makassar sebagai sastra Nusantara. Pembelajaran BM berfungsi sebagai (1) sarana pembinaan sosial budaya regional Sulawesi Selatan, (2) sarana peningkatan pengetahuan, keterampilan, dan sikap dalam rangka pelestarian dan pengembangan budaya, (3) sarana peningkatan pengetahuan, keterampilan, dan sikap untuk meraih dan mengembangkan ilmu pengetahuan, teknologi, dan seni, (4) sarana pembakuan dan penyebarluasan pemakaian BM untuk berbagai keperluan, (5) sarana pengembangan penalaran, serta (6) sarana pemahaman aneka ragam budaya daerah (Makassar).

$$
\text { Sejalan dengan fungsi tersebut, }
$$
pelaksanaan pembelajaran bahasa daerah termasuk BM bertujuan agar peserta didik: (1) memperoleh pengalaman berbahasa dan bersastra Makassar, (2) menghargai dan membanggakan BM sebagai bahasa daerah di Sulawesi Selatan yang juga merupakan bahasa ibu bagi sebagian besar masyarakat Makassar, (3) memahami BM dari segi bentuk, makna, dan fungsi, serta mampu 
menggunakannya secara tepat dan kreatif untuk berbagai konteks (tujuan, keperluan, dan keadaan), (4) mampu menggunakan BM untuk meningkatkan kemampuan intelektual, serta kematangan emosional dan sosial, (5) memiliki kemampuan dan kedisiplinan berbahasa Makassar, (6) mampu menikmati dan memanfaatkan karya sastra Makassar untuk meningkatkan pengetahuan dan kemampuan berbahasa Makassar, mengembangkan kepribadian, dan memperluas wawasan kehidupan, dan (7) menghargai dan membanggakan sastra Makassar sebagai khazanah budaya dan intelektual manusia Makassar. Ketujuh tujuan pembelajaran BM tersebut pada dasarnya mengacu kepada (1) tujuan praktis, (2) tujuan teoretis, dan (3) tujuan ideologis. Tujuan praktis ialah agar peserta didik memiliki penguasaan pasif (dapat memahami apa yang didengar dan dibacanya) dan penguasaan aktif (dapat berbicara dan menulis); tujuan teoretis ialah agar peserta didik memiliki pengetahuan tentang bahasa, yang dapat digunakannya untu penguasaan bahasa itu, dan tujuan ideologis ialah agar siswa memiliki sikap budaya (berbudaya) bagi bangsa yang memiliki bahasa itu.

Berdasarkan kajian teori yang berkaitan dengan materi pembelajaran bahasa Makassar, penulis menyimpulkan bahwa bahasa Makassar memiliki aspek kebahasaan dan kesastraan yang unik dan berbeda dengan bahasa daerah lain yang ada di Indonesia. Aspek kebahassaan (fonologi, morfologi, sintaksis, dan semantik) dan aspek kesastraan (puisi, prosa, dan drama) belum diajarkan secara maksimal sehingga siswa belum memahami secara mendalam bahasa dan sastra Makassar. Basang (1997) mengelompokkan karya sastra Makassar atas tiga jenis, yaitu: puisi (dowangang, paruntuk kana, kelong, dondo, rapang, aru, dan pakkiok bunting), prosa (paupau, patturioloang, dan rupama) dan bahasa berirama (royong dan sinrilik). Materi yang disajikan disusun secara secara sistematis yang terintegrasi dalam empat aspek keterampilan berbahasa Makassar, yaitu appinaknan (menyimak), akbicara (berbicara), ammaca (membaca), anngukirik (menulis).
Cunningsworth dalam Richard (1993) menyatakan bahwa bahan ajar harus: (1) sesuai kebutuhan pelajar, harus pula cocok dengan tujuan program pembelajaran bahasa, (2) memperlihatkan keterpakaian (sekarang dan akan datang) bahwa pelajar akan memiliki bahasa. Buku teks hendaknya dipilih yang dapat menjadi alat bantu siswa menggunakan bahasa secara efektif untuk tujuan mereka sendiri, (3) memperhitungkan kebutuhan siswa sebagai pelajar dan harus memfasilitasi proses belajar mereka tanpa terkesan mendogma dengan metode yang rinci, (4) mempunyai peranan yang jelas sebagai pendukung pembelajaran; dan (5) buku teks hendaknya menjembatani bahasa target pelajar.

Prinsip-prinsip yang dijadikan dasar dalam menentukan materi pembelajaran adalah kesesuaian (relevansi), keajegan (konsistensi), dan kecukupan (adequacy) (Depdiknas (2011). Selanjutnya, dalam penentuan cakupan materi pembelajaran harus pula diperhatikan apakah materi pembelajaran yang disajikan berupa aspek kognitif (fakta, konsep, prinsip, prosedur) aspek afektif, ataukah aspek psikomotor. Selain ketiga prinsip di atas, prinsip lain yang perlu digunakan dalam menentukan cakupan materi pembelajaran adalah keluasan, kedalaman dan, kecukupan materi.

Materi yang dikembangkan pada pembelajaran menyimak BM untuk siswa kelas VII, antara lain: memahami fonem bahasa Makassar, mengungkapkan contoh dan makna pappasang yang disimak, menjelaskan makna dan fungsi dowangang, dan mengungkapkan contoh paruntuk kana melalui kegiatan menyimak pembacaan wacana dan sastra Makassar. Hasil yang diharapkan dalam pengembangan model ini adalah yang sesuai dengan kebutuhan, yaitu adanya keterpaduan antara keterampilan menyimak, berbicara, membaca ,dan menulis dengan komponen kebahasaan dan kesastraan dalam BM. Ada beberapa hal yang perlu diperhatkan pembicara agar penyimak dapat memahami pesan yang disampaikan, yaitu: (a) ucapan pembicara harus baik, jelas, dan akurat, (b) menyatakan pokok pikiran dalam kalimat yang utuh, (c) 
mengembangkan pokok pikiran dengan memberikan penjelasan, uraian ataupun contoh, (d) menggunakan kalimat yang mudah dipahami penyimak, (e) menggunakan intonasi kalimat, ekspresi yang tepat, dan gerak tubuh yang sesuai untuk membantu pemahaman mitra tutur (Brown, 1994: 241). Materi yang disajikan dalam pembelajaran berbicara untuk siswa kelas VII, antara lain: Menggunakan sapaan dalam percakapan, bercakap-cakap dan menanggapi percakapan, melafalkan kalimat, dan menceritakan pengalaman melalui kegiatan bercerita dan bercakap-cakap, serta melantunkan kelong. Materi yang dikembangkan dalam pembelajaran membaca untuk siswa kelas VII, antara lain: memahami isi wacana narasi, membacakan naskah lontarak, membacakan pengumuman, dan membacakan karangan singkat melalui kegiatan membaca pemahaman dan membaca nyaring. Materi yang akan dikembangkan dalam pembelajaran menulis BM untuk siswa kelas VII, antara lain: mengekspresikan pikiran dan perasaan dalam bahasa Makassar secara tertulis melalui kegiatan menulis kosakata, kalimat, paragraf, dan wacana baik sastra maupun nonsastra yang ditulis dengan ejaan latin dan lontarak yang baik dan benar.

\section{METODE}

Penelitian ini tergolong jenis penelitian pengembangan dengan menggunakan desain penelitian pengembangan Four-D oleh Thiagarajan (1974:5) yang melalui empat tahap, yaitu (1) define (pendefinisian); (2) perencanaan ; (3) pengembangan, dan (4) penyebarluasan. Data diolah dengan menggunakan analisis deskriptif yang menggambarkan kelayakan produk materi pembelajaran yang telah dikembangkan. Materi pembelajaran yang dikembangkan ini diperuntukkan bagi siswa kelas VII SMP/MTs. yang mengajarkan BM. Wilayah pemakaian bahasa Makassar di Sulawesi Selatan, meliputi beberapa kabupaten dan kota, yaitu: Kota Makassar, Kabupaten Gowa, Kabupaten Takalar,
Kabupaten Jeneponto, Kabupaten Bantaeng, sebagian Kabupaten Bulukumba, sebagian Kabupaten Selayar, sebagian Kabupaten Maros, dan sebagian Kabupaten Pangkajeknek Kepulauan (Pelenkahu, 1974). Dialek yang digunakan dalam penulisan materi pembelajaran bahasa Makassar adalah bahasa Makassar Dialek Lakiung (BMDL) karena dialek Lakiung dijadikan dialek standar dalam bahasa Makassar.

Sumber data penelitian ini adalah tim ahli sebagai penilai uji kelayakan materi pembelajaran terdiri atas tiga orang pakar, yaitu: pakar pengajaran bahasa, pengajaran sastra, dan linguistik yang memahami tentang bahasa Makassar dan diujicobakan kepada guru BM pada tingkat SMP/MTs. di Kota Makassar sebagai praktisi di lapangan yang akan menggunakan produk ini sebagai bahan ajar BM. Hasil penilaian dari tim ahli dan uji coba praktisi (guru) dianalisis dengan menggunakan statistik persentasi. Instrumen Penilaian Buku Pelajaran Bahasa Indonesia yang disusun oleh Pusat Perbukuan, Badan Standar Nasional Pendidikan (BSNP) Depdiknas Tahun 2008. Data penilaian hasil uji kelayakan materi pembelajaran dari pakar dan uji coba lapangan dari praktisi dikelompokkan atas dua bagian, yaitu data kuantitatif dan data kualitatif. Data kuantitatif berupa skor penilaian uji kelayakan materi pembelajaran dari segi isi, bahasa, dan penyajian. Kategori kriteria tingkat kelayakan yang digunakan adalah:
4. $81-100 \%=$
3. $66-80 \%=$
2. $56-65 \%=$
1. $0-55=$
sangat layak
layak
kurang layak
tidak layak

Pilihan skala pada rentangan 1, 2, 3, dan 4 sebagai keputusan penyelesaian akhir yang diambil. Jika keputusan akhir yang dipilih pada skala 4 dan 3 maka tidak perlu direvisi. Akan tetapi, jika penyelesaian akhir yang dipilih pada skala 2 dan 1 maka produk materi pembelajaran masih perlu direvisi.

Bahasa Makassar adalah salah satu bahasa daerah di Indonesia yang digunanakan di jazirah Selatan Provinsi Sulawesi Selatan. Yang 
dimaksud pengembangan materi pembelajaran bahasa Makassar dalam penelitian ini adalah naskah tertulis yang berisi pengetahuan (kebahasaan, kesastraan, dan budaya Makassar), sikap (nilai-nilai kejujuran, saling menghormati, saling menolong, kepatuhan dan ketaatan, saling menyayangi, bertanggung jawab, disiplin, dan lain-lain), dan keterampilan (menyimak, berbicara, membaca, dan menulis) berbagai aspek kebahasaan dan karya sastra Makassar dengan ejaan Latin dan Lontarak untuk dipelajari siswa dalam rangka mencapai tujuan pembelajaran bahasa Makassar yang telah ditetapkan dalam Standar Kompetensi (SK) dan Kompetensi Dasar (KD).

\section{HASIL DAN PEMBAHASAN}

\section{Hasil}

Materi pembelajaran yang disajikan dirancang untuk dua semester. Setiap semester terdiri atas empat tema pembelajaran yang bervariasi. Adapun tema pembelajaran yang disajikan pada semester 1, meliputi: (1) Kikatutui Sossoranta, (2) Kikasukmangi pappasanna tau towata, (3) Maeki Sipakaingak, dan (4) Tutuki ri Kana-kana. Tema pembelajaran pada semester 2, yaitu: (1) Ingakki ri Panggaukang 'Hati-hatilah dalam perbuatan, (2) Entengangi Kalambusanga, (3) Kipakabajiki Ampe-ampeta, dan (4) Kikatutui Bonena Alanga. Tema pembelajaran disajikan secara terintegrasi dengan aspek kebahasaan dan kesastraan. Tema yang disajikan dalam materi pembelajaran mengandung nilai-nilai pendidikan karakter yang berlandaskan pada ajaran agama dan budaya yang diwariskan oleh leluhur.

Masalah yang dibahas dalam tulisan ini difokuskan pada aspek kelayakan sebuah materi pembelajaran yang meliputi: (1) kelayakan isi materi pembelajaran, (2) kelayakan bahasa materi pembelajaran, dan (3) kelayakan penyajian materi pembelajaran yang dinilai oleh tim ahli dan guru BM sebagai praktisi di lapangan. Temuan tersebut dapat menggambarkan keunggulan produk materi pembelajaran BM yang telah dikembangkan, khususnya untuk siswa kelas VII di Sulawesi Selatan yang mengajarkan BM.

\section{Penilaian Uji Kelayakan dari Pakar}

\section{a. Kelayakan Isi Materi Pembelajaran}

Aspek kelayakan isi materi pembelajaran mencakup tiga subkomponen, yaitu: (1) kesesuaian uraian dengan standar kompetensi (SK) dan kompetensi dasar (KD), (2) keakuratan materi, dan (3) pendukung materi pembelajaran. Subkomponen kesesuaian uraian dengan SK dan KD mengandung dua butir penilaian yaitu kelengkapan materi dan kedalaman materi; subkom-ponen keakuratan materi mengandung empat butir penilaian, yaitu: keakuratan pemilihan wacana, keakuratan konsep dan teori, keakuratan pemilihan contoh, keakuratan pelatihan; subkomponen pendukung materi pembelajaran mengandung enam butir penilaian, yaitu: kesesuaian denganper kembangan kebahasaan, kesesuaian dengan perkembangan kesastraan, kesesuaian fitur/contoh/latihan/rujukan, pengembangan wawasan kebhinekaan/kebudayaan Makassar, pengembangan wawasan karakter bangsa, dan menunjang mata pelajaran lain.

Data yang disajikan pada tabel berikut merupakan penilaian terakhir dari tim ahli setelah produk materi pembelajaran direvisi berdasarkan hasil penilaian sebelumnya, baik secara kuantitatif maupun kualitatif. Adapun penilaian tim ahli pada aspek kelayakan isi materi pembelajaran dapat dilihat pada tabel berikut. 
Tabel 1. Data Kelayakan Isi Materi Pembelajaran

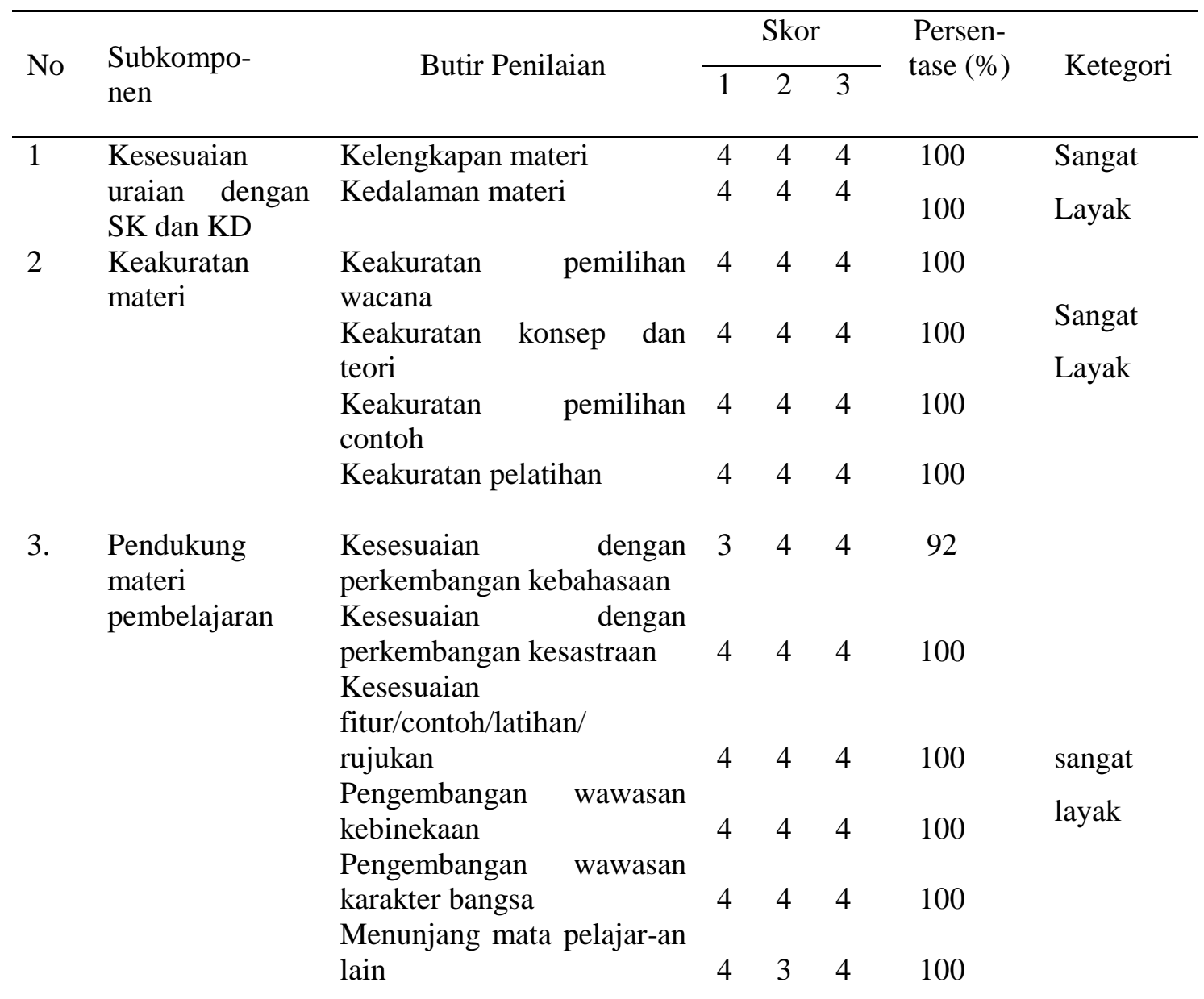

Data di atas menunjukkan bahwa subkomponen kesesuaian materi dengan SK dan $K D$ memperoleh skor rata-rata 4 atau tingkat persentase $100 \%$; subkomponen keakuratan materi memperoleh skor rata-rata 4 atau tingkat persentase $100 \%$, dan subkomponen pendukung materi pembelajaran memperoleh skor rata-rata 3,7 atau tingkat persentase $92 \%$ dan ada empat butir penilaian yang memperoleh skor rata-rata 4 atau tingkat persentase $100 \%$. Hal ini berati bahwa terjadi peningkatan perolehan skor setelah materi pembelajaran direvisi. Dengan mengacu kepada kriteria kelayakan materi pembelajaran, aspek kelayakan isi berada pada kategori sangat layak. Hal ini berarti bahwa isi materi pembelajaran yang disajikan sudah layak diajarkan kepada siswa kelas VII SMP yang mengajarkan BM.

\section{b. Kelayakan Bahasa Materi Pembelajaran}

Aspek kelayakan bahasa materi pembelajaran, mencakup tiga subkomponen, yaitu: (1) kesesuaian dengan tingkat perkembangan peserta didik, (2) kekomunikatifan, dan (3) keruntutan dan kesatuan gagasan. Ketiga subkomponen tersebut dibahas secara berurutan berdasarkan data dan analisis data yang telah dipaparkan. Subkomponen kesesuaian dengan tingkat perkembangan peserta didik terdiri dari tiga butir 
penilaian, yaitu: kesesuaian dengan tingkat perkembangan intelektual peserta didik, kesesuaian dengan tingkat perkembangan sosioemosional peserta didik, dan kesesuaian dengan tingkat perkembangan spritual peserta didik; subkomponen kekomunikatifan mencakup empat butir penilaian, yaitu: keterbacaan teks, ketepatan bahasa, ketepatan gambar dengan isi, dan ketepatan ejaan; subkomponen keruntutan dan kesatuan gagasan gagasan terdiri dari tiga butir penilaian, yaitu: keruntutan dan keter- paduan antarstandar kompetensi, keruntutan dan keterpaduan paragraf, dan keefektifan dan kegramatikalan kalimat.

Data yang disajikan pada aspek kelayakan bahasa materi pembelajaran bahasa Makassar juga merupakan penilaian terakhir dari tim ahli setelah beberapa kali direvisi. Data penilaian dari tim ahli dapat dilihat pada tabel berikut.

Tabel 2. Kelayakan Bahasa Materi Pembelajaran

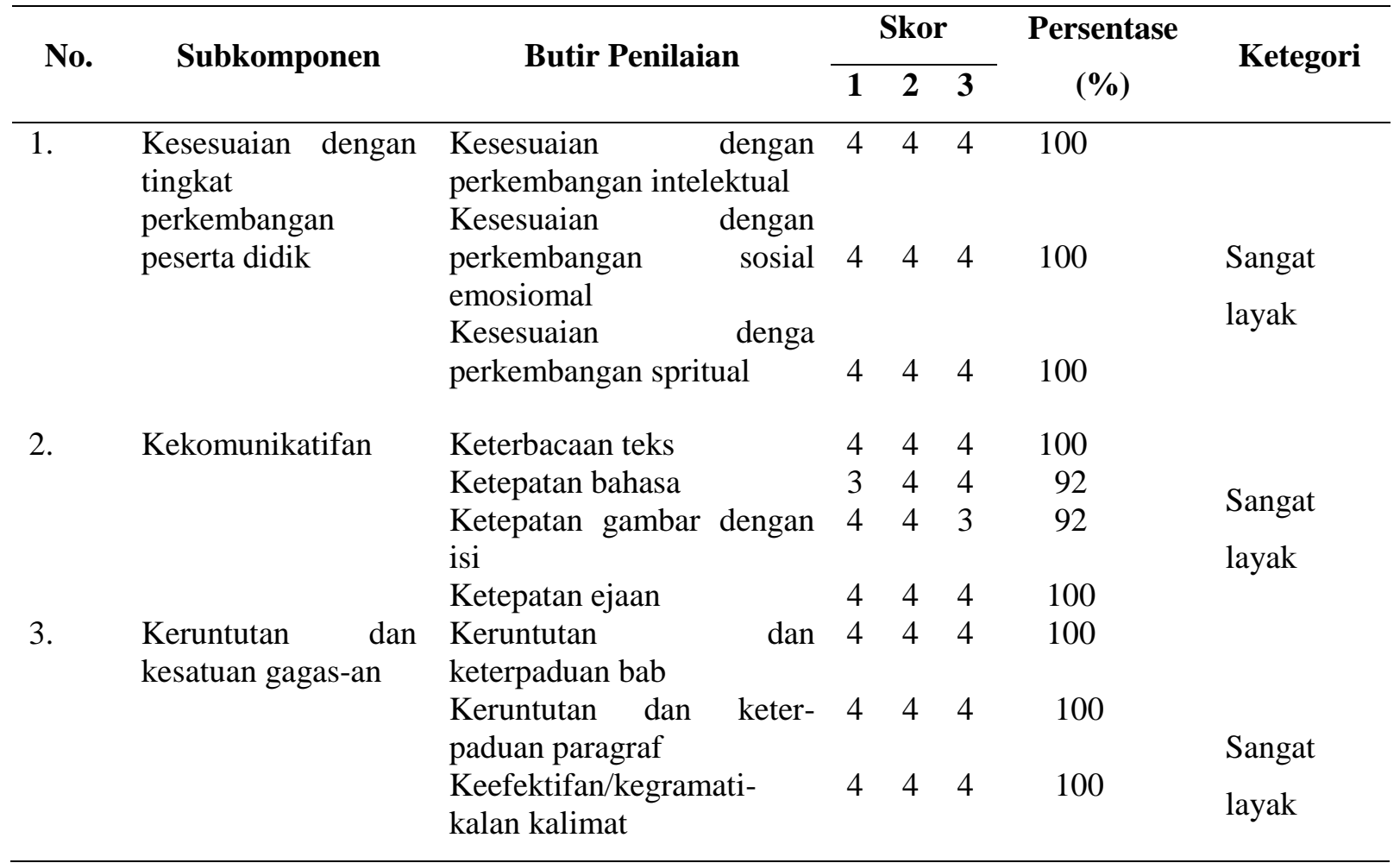

Data pada tabel di atas menunjukkan bahwa subkomponen kesesuaian dengan tingkat perkembangan peserta didik memperoleh skor rata-rata 4 dengan tingkat persentase 100\%; subkomponen kekomunikatifan memperoleh skor rata- rata 3,5 dengan tingkat persentase 96\%, dan subkomponen keruntutan dan kesatuan gagasan memperoleh skor rata-rata 4 dengan tingkat persentase $100 \%$. Dengan mengacu kepada kriteria kelayakan bmateri pembelajaran maka aspek kelayakan bahasa berada pada kategori sangat layak. Data kuantitatif di atas didukung oleh data kualitatif melalui catatan tim ahli pada rangkuman kualitatif. Ketiga ahli menyatakan bahwa materi pembelajaran ini sudah layak dari segi bahasa

Kelayakan Penyajian Materi Pembelajaran. Aspek kelayakan penyajian materi mencakup tiga subkomponen, yaitu:(1) teknik 
penyajian, (2) penyajian pembelajaran, (3) kelengkapan penyajian. Subkomponen teknik penyajian terdiri dari empat butir penilaian, yaitu: konsistensi sistematika penyajian, keruntutan konsep, dan keseim-bangan antarbab, dan keseimbangan antarstandar kompetensi; subkomponen penyajian pembelajaran terdiri dari tiga butir penilaian, yaitu: keterpusatan pada peserta didik, keterangsangan metakognisi peserta didik, dan keterangsangan daya imajinasi, kreasi, dan berpikir kritis peserta didik, dan subkomponen kelengkapan penyajian terdiri dari tiga butir, yaitu: bagian pendahuluan, bagian isi, dan bagian penutup.
Demikian halnya dengan aspek kelayakan isi dan bahasa materi pembelajaran, data kelayakan penyajian materi pembelajaran BM yang disajikan berikut merupakan penilaian terakhir dari tim ahli. Adapun data kelayakan penyajian materi pembelajaran $\mathrm{BM}$ dapat dilihat pada tabel berikut.

Tabel 3. Kelayakan Penyajian Materi Pembelajaran

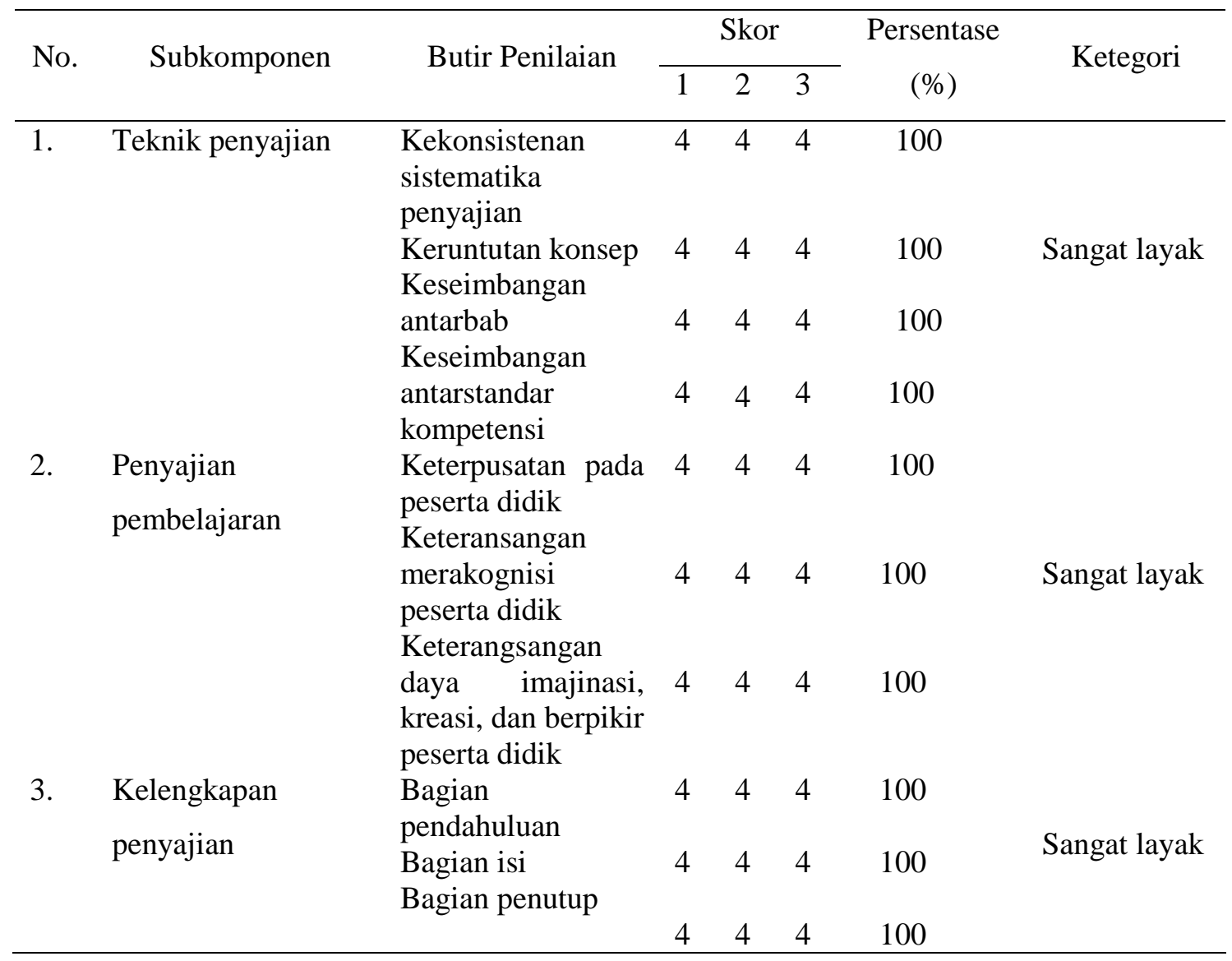

Data pada tabel di atas menunjukkan bahwa subkomponen teknik penyajian memperoleh skor rata-rata 4 atau tingkat persentase $100 \%$; subkomponen penyajian pembelajaran memperoleh skor rata-rata 4 atau tingkat persentase $100 \%$, dan subkomponen kelengkapan penyajian juga memperoleh skor 
rata-rata 4 atau tingkat persentase $100 \%$. Ketiga subkomponen aspek kelayakan bahasa berada pada kategori sangat layak. Data kuantitatif di atas didukung oleh data kualitatif melalui catatan tim ahli pada rangkuman kualitatif. Ketiga ahli menyatakan bahwa materi pembelajaran ini sudah layak dari segi penyajian.

\section{Hasil Uji Coba Kelayakan Materi Pembelajaran dari Guru/Praktisi di lapangan}

Guru merupakan salah satu faktor penting yang harus dilibatkan dalam uji coba kelayakan materi pembelajaran. Dengan dasar tersebut, guru dilibatkan sebagai sasaran uji coba kelayakan materi pembelajaran BM yang telah dikembangkan. Adapun rangkuman data penilaian dari praktisi (guru) di lapangan terhadap kelayakan materi pembelajaran BM siwa kelas VII SMP/MTs. dapat dilihat pada tabel berikut.

Tabel 4. Data Kuantitatif Kelayakan Isi Materi Pembelajaran oleh Praktisi (Guru) di Lapangan

\begin{tabular}{|c|c|c|c|c|c|c|c|c|c|c|}
\hline \multirow{2}{*}{ No } & \multirow{2}{*}{ Butir penilaian } & \multicolumn{6}{|c|}{ Skor } & \multirow{2}{*}{$\begin{array}{l}\text { Jmlh } \\
\text { skor }\end{array}$} & \multirow[t]{2}{*}{$\%$} & \multirow{2}{*}{ Kategori } \\
\hline & & 1 & 2 & 3 & 4 & 5 & 6 & & & \\
\hline 1. & Kelengkapan materi & 4 & 4 & 3 & 4 & 4 & 4 & 23 & 96 & $\begin{array}{l}\text { sangat } \\
\text { layak }\end{array}$ \\
\hline 2. & Kedalaman materi & 4 & 4 & 3 & 4 & 4 & 4 & 23 & 96 & $\begin{array}{l}\text { sangat } \\
\text { layak }\end{array}$ \\
\hline 3. & $\begin{array}{l}\text { Keakuratan pemilihan } \\
\text { wacana }\end{array}$ & 4 & 4 & 4 & 4 & 4 & 4 & 24 & 100 & $\begin{array}{l}\text { sangat } \\
\text { layak }\end{array}$ \\
\hline 4. & $\begin{array}{l}\text { Keakuratan konsep } \\
\text { dan teori }\end{array}$ & 4 & 4 & 4 & 4 & 4 & 4 & 24 & 100 & $\begin{array}{l}\text { sangat } \\
\text { layak }\end{array}$ \\
\hline 5. & $\begin{array}{l}\text { Keakuratan pemilihan } \\
\text { contoh }\end{array}$ & 4 & 4 & 4 & 4 & 4 & 4 & 24 & 100 & $\begin{array}{l}\text { Sangat } \\
\text { layak }\end{array}$ \\
\hline 6. & Keakuratan pelatihan & 4 & 4 & 3 & 4 & 4 & 4 & 23 & 96 & $\begin{array}{l}\text { sangat } \\
\text { layak }\end{array}$ \\
\hline 7. & $\begin{array}{l}\text { Kesesuaian dengan } \\
\text { perkembangan } \\
\text { kebahasaan }\end{array}$ & 4 & 4 & 3 & 4 & 4 & 4 & 23 & 96 & $\begin{array}{l}\text { sangat } \\
\text { layak }\end{array}$ \\
\hline 8. & $\begin{array}{l}\text { Kesesuaian dengan } \\
\text { perkembangan } \\
\text { kesastraan }\end{array}$ & 4 & 4 & 3 & 4 & 4 & 3 & 22 & 92 & $\begin{array}{l}\text { sangat } \\
\text { layak }\end{array}$ \\
\hline 9. & $\begin{array}{l}\text { Kesesuaian } \\
\text { fitur/contoh/latihan/ } \\
\text { rujukan }\end{array}$ & 4 & 4 & 3 & 4 & 4 & 4 & 23 & 96 & $\begin{array}{l}\text { sangat } \\
\text { layak }\end{array}$ \\
\hline 10. & $\begin{array}{l}\text { Pengembangan } \\
\text { wawasan } \\
\text { kebhinekaan/kebu- } \\
\text { dayaan Makassar }\end{array}$ & 4 & 4 & 4 & 4 & 4 & 3 & 23 & 96 & $\begin{array}{l}\text { sangat } \\
\text { layak }\end{array}$ \\
\hline 11. & $\begin{array}{l}\text { Pengembangan } \\
\text { wawasan karakter } \\
\text { bangsa }\end{array}$ & 4 & 4 & 4 & 4 & 4 & 3 & 23 & 96 & $\begin{array}{l}\text { sangat } \\
\text { layak }\end{array}$ \\
\hline 12. & $\begin{array}{l}\text { Menunjang mata } \\
\text { pelajaran lain }\end{array}$ & 4 & 4 & 3 & 4 & 3 & 3 & 21 & 88 & $\begin{array}{l}\text { sangat } \\
\text { layak }\end{array}$ \\
\hline
\end{tabular}


Data di atas menggambarkan bahwa materi pembelajaran yang telah dikembangkan sudah sesuai dengan kebutuhan di lapangan. Hasil penilaian guru BM, baik secara kuantitatif maupun kualitatif pada aspek kelayakan isi, bahasa, dan penyajian materi pembelajaran sama dengan penilaian tim ahli, yaitu berada pada kategori sangat layak (96\%).

\section{Pembahasan}

Sejalan dengan Model Four-D oleh Thiagarajan (1975), penelitian ini telah mengikuti langkah-langkah penelitian pengembangan. Langkah yang dilakukan pada tahap pendefinisian meliputi kegiatan analisis kurikulum bahasa Makassar, observasi bahan ajar yang telah ada, analisis peserta didik dan konfirmasi dengan guru, analisis materi, penentuan tujuan pembelajaran dan tugas, dan mengumpulkan materi. Setelah melalui tahap tersebut, peneliti melakukan perangcangan Silabus, RPP, Tugas, dan penyusunan materi pembelajaran. Hasil dari perancangan tersebut divalidasi oleh oleh ahli pengajaran, sastra, dan linguistik. Setelah materi pembelajaran dinyatakan layak oleh Tim Ahli, peneliti mengujicobakan secara terbatas kepada guru bahasa daerah di Kota Makassar. mulai dari pendefinisian, perancangan, pengembangan, dan desiminasi. Desiminasi produk materi pembelajaran masih terbatas pada guru sebagai praktisi dan belum disebarluaskan secara luas pada siswa pada saat arikel ini dimuat. Produk

Prinsip pengembangan ini sejalan dengan prinsip pengembangan materi pembelajaran oleh Sudaryat (2008). Penyajian materi pembelajaran disusun secara sistematis dari hal yang mudah ke hal yang sukar dan dari yang sederhana ke hal yang kompleks, seperti materi diawali dari tujuan pembelajaran, pengantar, contoh (kosakata, kalimat, paragraf, dan wacana sastra maupun nonsastra),.materi pembelajaran disajikan dalam dua semester dan setiap semester terdiri atas empat pelajaran dengan tema yang bervariasi. Tema yang dipilih disesuaikan dengan kompetensi dasar yang telah digariskan dalam standar isi kurikulum bahasa Makassar.
Strategi pempelajaran dilakukan secara terintegrasi antara aspek menyimak, berbicara, membaca, dan menulis.

Materi pembelajaran ini memuat aspek kognitif (pengetahuan), afektif (sikap), dan psikomotor (keterampilan) yang berkaitan dengan aspek kebahasaan dan kesastraan. Isi materi yang disajikan sesuai dengan pendapat Reigeluth dalam Depdiknas (2011). Materi pembelajaran dilengkapi gambar atau bagan yang sesuai dengan konteks dan kebutuhan peserta didik. Hal ini dimaksudkan agar menarik minat siswa untuk belajar bahasa Makassar. Pada materi sebelumnya, gambar yang disajikan belum bervariasi dan ada gambar yang tidak sesuai dengan konteks wacana. Bahasa yang digunakan dalam materi pembelajaran ini adalah bahasa Makassar dialek Lakiung (BMDL) karena dialek inilah yang dijadikan sebagai dialek standar dalam bahasa Makassar. Ejaan yang diterapkan dalam penulisan materi pembelajaran ada dua, yaitu ejaan Latin dan ejaan Lontarak (Basang, dkk, 1975.

Materi pembelajaran bahasa Makassar yang disusun melali hasil penelitian belum banyak dilakukan di Sulawesi Selatan sehingga produk yang dikembangkan memiliki beberapa keunggulan. Keunggulan produk materi pembelajaran ini dibanding materi pembelajaran sebelumnya adalah: (1) Materi pembelajaran dikembangkan berdasarkan $\mathrm{KD}$ dan Indikator serta tujuan pembelajaran, (2) Wacana yang disajikan lebih kontekstual Bahasa yang digunakan lebih komunikatif, (3) Latihan yang ditampilkan lebih bervariasi, (4) Materi pembelajaran sudah disertai gambar/foto/bagan yang sesuai dengan konteks, (5) Materi yang disajikan dapat melatih keterampilan dan sosioemosional peserta didik, (6) Dapat meningkatkan kreativitas guru dan siswa dalam pemilihan metode dan teknik pembelajaran, dan (7) Jenis materi yang dikembangkan mencakup aspek pengetahuan, keterampilan, dan sikap yang mencerminkan semangat kebudayaan Makassar 


\section{SIMPULAN DAN SARAN}

Berdasarkan hasil penelitian ini, dapat disimpulkan bahwa materi pembelajaran BM yang dikembangkan sudah memenuhi kriteria kelayakan dari segi isi, bahasa, dan penyajian.. Hal tersebut ditunjukkan oleh hasil analisi data bahwa ketiga aspek terbut mencapai kelayakan 92\% (kategori sangat layak dari Tim ahli dan 96\% dari uji coba praktisi (guru). Sehubungan dengan tenuan tersebut, penulis menyarankan beberapa hal, antara lain: (1) produk materi pembelajaran yang telah dikembangkan dapat digunakan sebagai salah satu bahan ajar bahasa Makassar untuk siswa SMP yang mengajarkan bahasa Makassar di sekolah, (2) perlunya penelitian pada aspek yang lain, seperti: pengembangan media pembelajaran $\mathrm{BM}$, model pembelajaran $\mathrm{BM}$, media pembelajaran $\mathrm{BM}$, pengembangan evaluasi, dan Lembar Kerja Siswa (LKS) bahasa Makassar, (3) perhatian pemerintah Provinsi Sulawesi Selatan terhadap bahasa, sastra, dan budaya Makassar harus lebih ditingkatkan dan dijadikan bahasa daerah sebagai mata pelajaran yang setara dengan mata pelajaran lain, (4) Model pembelajaran yang inovatif harus diterapkan oleh guru dalam pembelajaran bahasa Makassar agar siswa lebih termotivasi belajar bahasa Makassar sebagai salah satu kearifan lokal di Sulawesi Selatan.

Sehubungan dengan tenuan tersebut, penulis menyarankan beberapa hal, yaitu (1) perlunya penelitian pada aspek yang lain, seperti: pengembangan media pembelajaran $\mathrm{BM}$, model pembelajaran $\mathrm{BM}$, media pembelajaran $\mathrm{BM}$, pengembangan evaluasi, dan Lembar Kerja Siswa (LKS) bahasa Makassar, (2) perhatian pemerintah Provinsi Sulawesi Selatan terhadap bahasa, sastra, dan budaya Makassar harus lebih ditingkatkan dan dijadikan bahasa daerah sebagai mata pelajaran yang setara dengan mata pelajaran lain, (3) Model pembelajaran yang inovatif harus diterapkan oleh guru dalam pembelajaran bahasa Makassar agar siswa lebih termotivasi belajar bahasa Makassar sebagai salah satu kearifan lokal di Sulawesi Selatan.

\section{DAFTAR RUJUKAN}

Ali Ibrahim, Gufran. 2011. "Bahasa Terancam Punah: Fakta, Sebab-Musabab, Gejala, dan Strategi Perawatannya" dalam Jurnal Ilmiah Masyarakat Linguistik Indonesia Tahun ke-29, Nomor 1. Jakarta: Masyarakat Linguistik Indonesia.

Alim, Sumarno. Kriteria Pemilihan Materi Pelajaran." Online: 28 Juli 2011, diakses Tanggal 2 Januari 2012.

Alwi, Hasan, dkk. (ed). 2003. Politik Bahasa, Rumusan Seminar Politik Bahasa.

Jakarta:Pusat Bahasa Departemen Pendidikan nasional..

Amir, Johar. 2010. "Pola Pemilihan Bahasa Ranah Keluarga di Kabupaten Pangkajene Kepulauan" Disertasi. Makassar: PPS Universitas Hasanuddin.

Basang, Djirong. 1997. Taman Sastra Makassar. Ujung Pandang: UD Mandiri.

Brown, H.D. 1994. Principles of Language Learning and Teaching. Eaglewood Cliffds: Prentice Hall.

Brown, J.D. 1995. The Elements of Language Curriculum. NY: Heinle Pub.

Chomsin in S. Widodo. 2002 Panduan Menyusun Bahan Ajar Berbasis Kompetensi. Jakarta: Kompas Gramedia.

Daeng, Kembong. 2013. "Pengembangan Materi Pembelajaran Bahasa Makassar Siswa Kelas VII SMP/MTs di Sulawesi Selatan". Laporan Penelitian Disertasi. Makassar: Universitas Negeri Makassar.

Depdiknas. 2003. Undang-Undang No. 20 Tahun 2003 tentang Sistem Pendidikan

Nasional. Jakarta.

Depdiknas. 2008. Panduan Materi Pembelajaran Pengembangan. Jakarta: Dirjen Manajemen Pendidikan Dasar dan Menengah, Direktorat Pendidikan Sekolah Menengah Atas.

Depdiknas. 2008. Instrumen dan Deskripsi Penilaian Buku Teks Pelajaran

Bahasa Indonesia SMP/MTs. Pusat Perbukuan Badan Standar Nasional Pendidikan 
Gagne, Robert M dan Briggs Leslie. 1978. Principles of Instructional Design. New York: Chicago San Fransisco Dallas Montreal Toronto London Sidney.

Kurnia, Ganjar. "Mengoptimalkan Kekhasan Lokal" dalam Filed under:Inohong Seni dan Budaya, Kliping Media Massa Posted by: Eep. Sumber:umpad.ac.id Diakses 10 April 2011.

Kusrianto. 2009. Menulis Buku Ajar dan Referensi. Jakarta: Grasindo.

Maknum, Tajuddin. 2012. Nelayan Makassar Kepercayaan, Karakter. Makassar: Identitas Universitas Hasanuddin.

Nurhadi, dkk. 2003. Pembelajaran Kontekstual dan Penerapannya dalam KBK. Malang: PN Universitas Negeri Malang.

Pannen, P \& Purwanto. 2001. Penulisan Bahan Ajar. Jakarta: PAU-PPAI UT.

Pelenkahu. 1974. Peta Bahasa Sulawesi Selatan. Ujung Pandang. Peraturan Pemerintah RI No. 19 Tahun 2005 tentang Standar Nasional Pendidikan. 2005. Jakarta.

Richards, J.C. \& Rodgers, T.S. 1993. Approaches and Methods in Language Teaching. Cambridge: Cambridge University Press.

Sudaryat, Yayat. 2008. Modul Pembelajaran Bahasa Daerah. Bandung: Universitas Pendidikan Indonesia.

Sugiyono. 2010. Metode Penelitian Kuantitatif, Kualitatif, dan R\&D. Bandung: PN: Alfabet.

Suherdi, Didi. 2005. "Peran Sentral Interaksi dalam Proses Belajar-Mengajar Bahasa" dalam Jurnal Bahasa \& Sastra, Vol. 6, No. 1, April 2006.

Suparman, Atwi. 1993. Desain Instruksional. Jakarta: Pusat Antar Universitas untuk PPAI Ditjen Dikti Depdikbud.

Thiagarajan, Sivasailam dkk.. 1975. Instructional Development for Training Teachers of Exceptional Children. Indiana:Cana University.

Undang-Undang Nomor 24 Tahun 2009 tentang Bendera, Bahasa, dan Lambang Negara, serta Lagu Kebangsaan 2009. Jakarta: PN Pustaka Yustisia. 